ISLAMIC BANKING Volume 5 Nomor 1 Edisi Agustus 2019| 1

\title{
PENGELOLAAN SUMBER DAYA INSANI DALAM MEMASARKAN PRODUK DAN JASA LEMBAGA KEUANGAN SYARIAH
}

\author{
Melis \\ Fakultas Ekonomi dan Bisnis Islam UIN Raden Fatah Palembang \\ Email: melis_UIN@radenfatah.ac.id
}

\begin{abstract}
This research discusses the management of human resources in marketing the products and services of Islamic financial institutions. The results of this study prove that Islamic banks and financial institutions in Indonesia are developing very fast. However, the image of banks and Islamic financial institutions in Indonesia is not good. For this reason, several policies in managing Islamic financial institutions need to be addressed. One of them is the aspect of human resources. An employee of a bank and an Islamic financial institution that is accepted must have a good personality, an expert in muqalah fiqh, knowledge of Islamic financial institutions, computers / IT and so on. They must be people who support strongly to practice Islamic economics in their lives.
\end{abstract}

Keyword: Human Resources, Banks, Islamic Finance, Indonesia

\section{Dasar Pemikiran (Times New Roman 12, Bold)}

Siapapun tidak dapat menyangkal bahwa faktor manusia merupakan sentral dari setiap aktivitas maupun peristiwa di dunia ini. Majunya peradaban manusia merupakan buah karya kreativitas dan inovatifnya manusia. Menurunnya kualitas lingkungan hidup juga diakibatkan kecerobohan dan keserakahan manusia.

Dalam lingkup yang lebih sempit, misalnya pada sebuah perusahaan, manusia atau faktor sumber daya insani tetap menjadi kunci maju mundurnya perusahaan tersebut. Sebuah perusahaan manufaktur yang menerapkan teknologi canggih, menggunakan bahan baku pilihan, modal yang cukup, metode kerja terbaik, serta didukung oleh pasar yang potensial akan menjadi tak berarti apa-apa jika aspek sumber daya insani (manusia) tidak berfungsi sebagaimana mestinya. Mesin berteknologi tinggi hanya akan beroperasi baik jika dijalankan operator yang mahir dan menguasai cara kerja mesin tersebut. Modal atau dana yang berlimpah hanya akan bermanfaat secara optimal jika dikelola seorang manejer keuangan yang handal mengelola keuangan. Pasar yang potensial hanya akan bisa digarap dan dikuasai perusahaan jika manejer pemasarannya mampu merancang program-program pemasaran yang menyentuh hati dan 


\section{2 | Melis PengelolaAN SUMBer daya INSANI DALAM MEMASARKAN PRODUK......}

menumbuhkan minat konsumen, di sisi lain ia harus mampu mengelola pemasaran di tengah membanjirnya produk perusahaan pesaing. Beberapa hal di atas untuk sementara telah bisa menunjukkan betapa faktor sumber daya insani (manusia) merupakan faktor yang sangat penting untuk dikelola dengan baik dalam setiap organisasi termasuk organisasi bisnis/perusahaan.

Faktor sumber daya insani atau karyawan perusahaan perlu dikelola dengan sebaikbaiknya sehingga dapat berperan optimal dan memberikan kontribusi terbaik bagi kemajuan perusahaan. Perusahaan mempelajari faktor lingkungan melalui pengamatan cermat. Artinya, perusahaan perlu mengumpulkan berbagai informasi persoalan lingkungan secara teratur dan menafsirkannya dalam kaitannya dengan bisnis perusahaan. Pengamatan merupakan tahap awal dalam memformulasi strategi dan perencanaan strategis. Sebuah pengamatan dan prakiraan dikembangkan sebagai dasar pembuatan perencanaan. Aspek penting dalam menganalisis industri adalah menentukan faktor-faktor keberhasilan usaha di pasar. Faktor-faktor tersebut antara lain berupa, produk, promosi, harga, dan tempat. Sekedar sebagai contoh, untukberhasil dalam usaha makanan cepat saji, sebuah perusahaan harus memiliki lokasi yang meyakinkan, pelayanan cepat, standar kualitas produk yang taat asas, kebersihan, penyimpanan, dan harga bersaing. Perusahaan seperti Mc. Donalds, Wendy's, KFC, Burger King, dan Bakmie Gajahmada serta Indofood berhasil karena mereka memiliki karakteristikkarakteristik di atas (Mangkuprawira, 2004: 23).

Faktor-faktor keberhasilan untuk industri lain dapat berbeda. Sebagai contoh, toko swalayan, faktor-faktor pendukung keberhasilannya dapat berupa lokasi yang strategis, produk dengan berbagai macam pilihan yang menarik, pelayanan yang baik, produk yang bermutu, kenyamanan ruangan, dan sebagainya. Jadi, hal penting adalah sebuah perusahaan harus mengetahui faktor-faktor keberhasilan kritis dari industri dan memformulasi strategi yang tepat untuk memenuhi faktor-faktor di atas. Hal demikian tidak lepas dari unsur tenaga kerja/karyawan atau Sumber Daya Insani (SDI).

Strategi SDI didasarkan pada keseluruhan strategi perusahaan dan kebutuhan taat asas. Toko swalayan, misalnya, menekankan keramah-tamahan terhadap pelanggan. Oleh sebab itu perusahaan harus menyewa, melatih dan menghargai karyawan sehingga 
ISLAMIC BANKING Volume 5 Nomor 1 Edisi Agustus 2019 | 3

jasa-jasa pelayanan dapat mereka sediakan dengan efektif dan efisien (Mangkuprawira, 2004: 23).

Demikian juga halnya dengan perusahaan yang bergerak di bidang perbankan dan lembaga keuangan syariah (asuransi syariah, koperasi syariah, BMT, perusahaan pembiayaan syariah, dan lainnya) maka faktor sumber daya insani yang dimilikinya menjadi salah satu penentu kesuksesan perusahaan dalam menjalankan usahanya. Tidak dapat dipungkiri, khususnya di Indonesia, pertumbuhan lembaga keuangan syariah cukup melejit. Indikatornya antara lain banyaknya berdiri lembaga bank umum syariah, bank unit usaha syariah, asuransi syariah, bank pembiayaan rakyat syariah, maupun lembaga keuangan mikro syariah lainnya. Pertumbuhan lembaga keuangan syariah ini tentunya harus diimbangi dengan ketersediaan sumber daya insani yang handal di bidang lembaga keuangan syariah. Hal ini perlu menjadi perhatian khusus karena adanya karakteristik dan ketrampilan khusus yang perlu dimiliki setiap orang yang berkecimpung di perusahaan lembaga keuangan syariah. Seharusnya tidak semua lulusan perguruan tinggi (fresh graduate) langsung dapat dipekerjakan di perusahaan lembaga keuangan syariah karena mereka setidaknya harusmemiliki kelebihan pengetahuan di bidang fiqh muamalat, hukum bisnis syariah, akuntansi syariah, etika bisnis islam, pemasaran syariah dan lainnya.

\section{Pembahasan}

Islam merupakan ajaran yang komprehensif. Islam tidak hanya mengatur hal-hal yang bersifat ibadah namun juga hal-hal yang berkaitan dengan hubungan sesama manusia dan mahluk lainnya. Tujuannya adalah agar tugas manusia sebagai hamba Allah dan juga sebagai khalifah dapat terlaksana dengan sempurna.

Salah satu aspek yang timbul dalam hubungan sesama manusia adalah aspek perekonomian. Islam memberikan aturan-aturan yang jelas dalam hal perekonomian, salah satunya yaitu tentang pelarangan riba. Riba secara etimologi berasal dari Bahasa Arab yang memiliki arti pertambahan, kelebihan, pertumbuhan, atau peningkatan. Adapun menurut istilah teknis, riba merupakan pengambilan tambahan dari harta pokok (modal) secara batil (Wibowo dan Widodo, 2005: 55). 
4 | Melis PengelolaAn SUmber daya insani dalam memasarkan PROdUK.......

Riba juga sering diartikan sebagai mengambil tambahan dari harta pokok atau modal secara batil yang sangat dilarang dalam ajaran Islam (Aravik, 2016: 15). Sebagaimana disebutkan dalam surah Al-Baqarah ayat 275

"Orang-orang yang makan (mengambil) riba tidak dapat berdiri melainkan seperti berdirinya orang yang kemasukan setan lantaran (tekanan) penyakit gila. Keadaan mereka yang demikian itu, adalah disebabkan mereka berkata (berpendapat), sesungguhnya jualbeli itu sama dengan riba, padahal Allah telah menghalalkan jual beli dan mengharamkan riba. Orang-orang yang telah sampai kepada mereka larangan dari Tuhannya, lalu terus berhenti (dari mengambil riba), maka baginya apa yang telah diambilnya dahulu (sebelum datang larangan) dan urusannya (terserah) kepada Allah. Orang yang kembali (mengambil riba), maka orang itu adalah penghuni-penghuni neraka, mereka kekal di dalamnya.

Islam melarang riba karena akibat-akibat buruk yang ditimbulkannya. Penghapusan riba merupakan keniscayaan. Menurut al-Ghazali mempraktekkan riba itu sama artinya dengan memenjarakan uang sedemikian rupa sehingga uang tidak dapat memainkan fungsi-fungsi utamanya. Di masyarakat, praktek ini tentu membawa implikasi yang serius pada terciptanya penipuan, kezaliman, dan ketidakadilan sosio-ekonomi (Aravik, 2017: 98). Untuk menghindari keburukan yang ditimbulkan praktik riba dikembangkanlah institusi bank dan lembaga keuangan syariah yang beroperasi tanpa bunga. Ekonomi tanpa bunga telah dilaksanakan pada permulaan Islam yang tidak sama dengan sistem kapitalis maupun komunis, namun merupakan gabungan sifat istimewa dari keduanya. Ia telah menciptakan perkembangan yang baik bagi masyarakat Islam di masa lalu, dimana tidak ada penimbunan kekayaan bagi setiap individu, tidak mengenal penyembunyian kekayaan dan tidak menarik keuntungan bagi diri sendiri (Muslehuddin, 1994: 50).

\section{Perkembangan Lembaga Keuangan Syariah}

Pada tahun 1963,di desa Mit Ghamr Savings Bank atau biasa disebut Mit Ghamr Bank yang dipelopori oleh seorang ekonom bernama Dr.Ahmad EL Najjar. Lembaga keuangan tersebut ternyata sangat sukses,baik dalam penghimpunan modal dari masyarakat berupa tabungan,uang titipan dan zakat,sadaqah,infak,maupun dalam 
ISLAMIC BANKING Volume 5 Nomor 1 Edisi Agustus 2019 | 5

memberikan modal kepada masyarakat yang berpenghasilan rendah,terutama di bidang perdagangan dan industry.

Dalam operasinya,Mir Ghamr Bank tidak membebankan bunga pada peminjam maupun membayar bunga kepada penabung.Bank ini melakukan investasi secara langsung maupun dalam bentuk kemitraan dengan pihak lain dan selanjutnya membagi keuntungan dengan para penabung.

Keberhasilan Mit Ghamr Bank menginspirasi banyak pihak untuk melakukan hal yang sama,antara lain sebagai berikut.

1. Pemerintah Mesir di bawah pemerintahan Gamal Abdul Naser membentuk Naser social Investment dengan basis perkotaan pada tahun 1972.

2. Masyarakat cendekiawan dan professional di Filipina membentuk Bank Amanah pada taahun 1973.

3. Organisasi konferensi Islam (OKI) yang beranggotakan pemerintah berbagai negara berpenduduk Muslim mendirikan Islamic Development Bank (IDB) pada tahun 1973 dan mulai beroperasi tahun 1975 dengan kantor pusat di Jeddah (https://www.kompasiana.com/dina07699/5af7e7cc16835f43227b1114/perkemban gan-lembaga-keuangan-syariah?page=all).

Sedangkan perkembangan lembaga perbankan dan keuangan di Indonesia diawali dengan berdirinya Bank Muamalat Indonesia (BMI) pada tahun 1991 dan beroperasi secara efektif pada tahun 1992.Indonesia terbilang terlambat dalam mengembangkan lembaga keuangan syariah dibandingkan dengan negara tetangga Malaysia yang telah mendirikan Bank Islam semenjak tahun 1983 (https://www.kompasiana.com/noviramadhani/5bceacf6677ffb7d266a8a47/perkembangan-lembaga-perbankan-dankeuangan-syariah-di-indonesia).

\section{Problematika Lembaga Keuangan Syariah}

Keberhasilan bank syariah dalam menghimpun dana masyarakat sangat berkaitan dengan kemampuan bank syariah dalam menjangkau lokasi nasabahnya. Semakin banyak jumlah kantor cabang, maka jumlah masyarakat yang menyimpan dana maupun melakukan pembiayaan di bank syariah semakin bertambah pula. 


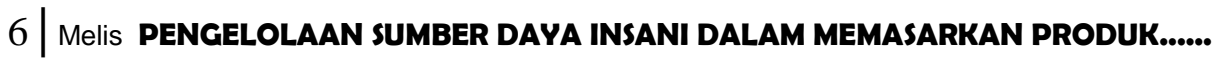

Potensi dan prospek perbankan syariah nampaknya sangat bagus untuk dikembangkan di Indonesia. Prospek yang baik ini setidaknya ditandai oleh beberapa hal. Pertama, jumlah penduduk muslim yang mayoritas di indonesia merupakan pasar potensial bagi perkembangan bank syariah. Kedua, perkembangan lembaga pendidikan tinggi yang menyelenggarakan pendidikan di bidang ekonomi dan keuangan syariah yang kian pesat. Ketiga, adanya fatwa Majelis Ulama Indonesia (MUI) tentang keharaman bunga bank. Keempat, dari pemerintah untuk mendukung perkembangan bank syariah cukup positif dengan diterbitkannya sejumlah peraturan dan undangundang tentang perbankan syariah (Sutedi, 2009: 45).

Pertumbuhan lembaga keuangan syariah di tanah air yang cukup menggembirakan bukannya tidak menghadapi berbagai macam permasalahan. Kurangnya sosialisasi dan pemahaman masyarakat yang masih kurang baik tentang produk dan jasa lembaga keuangan syariah, ada stigma yang menyebutkan bahwa syariah hanya untuk kalangan muslim saja, keterbatasan jumlah tenaga kerja atau sumber daya insani yang kompeten, dan segudang masalah lainnya.

\section{Peranan Sumber Daya Insani dalam Organisasi dan Kaitannya dengan Kegiatan Pemasaran.}

Seperti kita ketahui sumber daya yang dimiliki organisasi sering kita kenal dengan 6M yaitu (tenaga kerja atau karyawan), (dana atau modal), (Bahan baku), (cara kerja atau teknologi), (peralatan dan mesin-mesin), dan (pasar). Dari keenam sumber daya tersebut unsur tenaga kerja atau karyawan merupakan yang paling penting. Alasannya karena semua unsurtersebut kecuali unsur tenaga kerja atau karyawan merupakan benda mati yang tidak dapat berbuat apa-apa kecuali digerakkan dan diatur oleh manusia.

Bisnis perbankan merupakan bisnis yang jasa yang sangat tergantung kepada kepercayaan nasabah dalam bertransaksi dengan bank tersebut. Rasa percaya nasabah kepada bank dan lembaga keuangan syariah akan tumbuh berdasarkan pengalamannya bertransaksi dengan lembaga tersebut. Jika ia mendapatkan pelayanan yang tepat waktu, pelayanan yang benar-benar sesuai syariah, pembukuan yang transparan dan jujur, sapaan yang tulus dan ramah dari karyawan, keuntungan yang sesuai, keamanan dan kenyamanan yang terjamin maka bisa dipastikan nasabah tersebut akan merasa puas. 
ISLAMIC BANKING Volume 5 Nomor 1 Edisi Agustus $2019 \mid 7$

Semua pelayanan yang diimpikan nasabah yang disebutkan di atas tadi hanya akan mampu disajikan oleh karyawan yang terpilih dan trampil. Di sinilah peran penting manejer sumber daya insani dan kaitannya dengan kegiatan pemasaran produk dan jasa perusahaan. Dapat disimpulkan bahwa kegiatan pemasaran produk dan jasa perusahaan akan sukses jika ditopang penuh, tepat, terintegrasi, dinamis, dan sinergis dengan pengelolaan sumber daya insani perusahaan.

\section{Fungsi Manajemen Sumber Daya Insani Organisasi (Perspektif Islam)}

1. Perencanaan

Perencanaan (human resources planning) adalah merencanakan tenaga kerja secara efektif dan efisien agar sesuai dengan kebutuhan perusahaan dalam mencapai tujuan perusahaan. Perencanaan dilakukan dengan menetapkan program kepegawaian. Program kepegawaian meliputi pengorganisasian, pengarahan, pengendalian, pengadaan, pengembangan, kompensasi, pengintegrasian, pemeliharaan, kedisiplinan, dan pemberhentian karyawan. Program kepegawaian yang baik akan membantu tercapainya tujuan perusahaan, karyawan dan masyarakat.

2. Pengorganisasian

Pengorganisasian adalah kegiatan untuk mengorganisasi semua karyawan dengan menetapkan pembagian kerja, hubungan kerja, delegasi wewenang, integrasi, dan koordinasi dalam bagan organisasi. Organisasi hanya alat untuk mencapai tujuan. Dengan melaksanakan pengorganisasian yang baik akan membantu terwujudnya tujuan secara efektif (Hasibuan, 2011).

3. Pengarahan

Pengarahan (directing) adalah kegiatan mengarahkan semua karyawan, agar mau bekerja sama dan bekerja efektif serta efisien dalam membantu tercapainya tujuan perusahaan, karyawan, dan masyarakat. Pengarahan dilakukan pemimpin dengan menugaskan bawahan agar mengerjakan semua tugasnya dengan baik. Islam mengajarkan seorang pemimpin harus mengayomi bawahannya dan mendengarkan aspirasi mereka dalam pengambilan keputusan. 
8 | Melis PengelolaAn SUmber daya insani dalam memasarkan PROduK.......

4. Pengendalian

Pengendalian (controlling) adalah kegiatan mengendalikan semua karyawan agar mentaati peraturan-peraturan perusahaan dan bekerja sesuai dengan rencana. Apabila terdapat penyimpangan atau kesalahan, diadakan tindakan perbaikan dan penyempurnaan rencana. Pengendalian karyawan meliputi kehadiran, kedisiplinan, perilaku, kerjasama, pelaksanaan pekerjaan, dan menjaga situasi lingkungan pekerjaan.

\section{Simpulan}

Perkembangan bank dan lembaga keuangan syariah yang semakin pesat dewasa ini merupakan sesuatu yang patut disyukuri. Dengan perkembangan bank dan lembaga keuangan syariah yang semakin pesat ini diharapkan kegiatan perekonomian umat akan semakin maju dan mampu menunjukkan bahwa Islam bukan hanya sekedar ajaran yang berupa konsep saja tetapi bisa diaktualisasikan dalam berbagai aspek kehidupan. Islam mampu membuktikan kebenarannya sebagai rahmatan lil alamin.

Di sisi lain, perkembangan bank dan lembaga keuangan syariah ini perlu dibarengi dengan penyediaan sumber daya insani yang kompenten, handal, dan profesional dalam bidang ekonomi dan bisnis syariah. Masyarakat benar-benarmenantikan pelayanan bank dan lembaga keuangan syariah yang menentramkan dan menguntungkan. Salah satu kuncinya adalah pada aspek sumber daya insani/karyawan yang dimiliki perusahaan. Paradigma pengelolaan sumber daya insani di bank dan lembaga keuangan syariah saat ini perlu disempurnakan dan ditata ulang agar tercipta suatu lembaga keuangan syariah yang ideal. Rekrutmen karyawan bank dan lembaga keuangan syariah harus benar-benar mengutamakan kompetensi, bebas dari kecurangan, serta terencana dengan baik. Proses pengembangan karyawan harus secara dilakukan secara berkesinambungan dan menunjukkan distingsi kesyariahan.

Pemberian kompensasi harus diberikan secara adil, layak, dan tepat waktu agar dapat meningkatkan moral kerja dan semangat kerja karyawan. Pembinaan semangat kerja dan memotivasi karyawan harus tetap dilaksanakan dalam suasana kekeluargaan dan sesuai dengan nilai-nilai Islam sehingga terbentuk suatu lembaga yang benar-benar sesuai syariah. Bank dan lembaga keuangan syariah harus benar-benar menjadi teladan 
ISLAMIC BANKING Volume 5 Nomor 1 Edisi Agustus $2019 \mid 9$

dalam memanusiakan pekerjanya. Setiap karyawan merupakan bagian dari keluarga besar perusahaan yang perludiperhatikan bukan hanya ketika ia aktif menjadi karyawan perusahaan tetapi bahkan setelah pensiun ia masih merasa menjadi bagian penting dari perusahaan.

Jika hal-hal di atas dapat dilaksanakan dalam pengelolaan sumber daya insani/karyawan bank dan lembaga keuangan syariah maka diharapkan bank dan lembaga keuangan syariah akan lebih maju di masa depan dan dapat memainkan peranan penting dalam mensejahterakan umat manusia. Keluhan masyarakat yang menyatakan bahwa bank dan lembaga keuangan syariah sama saja dengan bank konvensional sedikit demi sedikit akan terkikis habis. 
10 Melis PengelolaAn SUMBer daya INSANI DALAM MEMASARKAN PRODUK.......

\section{DAFTAR PUSTAKA}

Adrian Sutedi, 2009. Perbankan Syariah: Tinjauan dan Beberapa Segi Hukum. Bogor: Ghalia Indonesia

Aravik, Havis, 2016, Ekonomi Islam; Teori, Konsep dan Aplikasi Serta Pandangan Pemikir Ekonomi Islam dari Abu Ubaid Sampai Al-Maududi, Malang: Empat Dua.

Aravik, Havis, 2017, "Esensi Zakat Sebagai Instrumen Finansial Islami dalam Pandangan Muhammad Nejatullah Siddiqi”, Jurnal Economica Sharia, Volume 2, Nomor 2, Februari 2017.

Departemen Agama, 2005. Al-Qur'an dan Terjemahannya. Bandung: CV. Diponegoro

Edy Wibowo dan Untung Hendy Widodo, 2005. Mengapa Memilih Bank Syariah. Bogor: Ghalia Indonesia

Hasibuan, Malayu S.P. 2011. Manajemen Sumber Daya Manusia. Jakarta: Bumi Aksara

Heri Sudarsono, 2007. Bank dan Lembaga Keuangan Syariah: Deskripsi dan Ilustrasi. Yogyakarta: Ekonisia

Iman Hilman, 2003. Perbankan Syariah Masa Depan. Jakarta: Senayan Abadi Publishing

Muhammad Muslehuddin, 1994. Sistem Perbankan dalam Islam, Diterjemahkan dari, Banking and Islamic Law'oleh Aswin Simamora. Jakarta: Rineka Cipta

Muhammad Sulaiman \& Aizuddinur Zakaria, 2010. Jejak Bisnis Rasul. Jakarta: Penerbit Hikmah

Muhammad Thalib, 2008. 40 Pedoman Membina Etos \& Semangat kerja Islami. Yogyakarta: Ma'alimul Usrah

Susilo Martoyo, 2000. Manajemen Sumber Daya Manusia. Yogyakarta: BPFE

Syafri Mangkuprawira, 2004. Manajemen Sumber Daya Manusia Strategik. Jakarta: Ghalia Indonesia 